\title{
Tipe Kepribadian dan Status Kesehatan Mental pada Kelompok Risiko Tinggi HIV/AIDS di Wilayah Kerja Puskesmas Ngemplak I
}

\author{
Personality Type and Mental Health Status in the High Risk Group for HIV/AIDS in the Working \\ Area of Ngemplak I Community Health Center
}

Michael Aaron Romulo ${ }^{1}$, Wulandari Berliani Putri ${ }^{*}$

${ }^{1}$ Dokter Puskesmas Ngemplak I, Sleman, D.I. Yogyakarta

*Penulis korespondensi. Wulandari Berliani Putri. Email: wulandari.berliani@gmail.com

\begin{abstract}
ABSTRAK
Pendahuluan: Lelaki Suka Lelaki (LSL) dan transgender merupakan sebagian dari kelompok yang beresiko tinggi mendapatkan HIV/AIDS. Meningkatnya morbiditas dan mortalitas kasus HIV/AIDS di Indonesia harus diimbangi dengan upaya pencegahan dan pengenalan dini faktor yang berkontribusi. Pengenalan kepribadian dan status kesehatan mental kelompok resiko tinggi sedini mungkin dapat mencegah timbulnya perjalanan penyakit atau gangguan yang lebih serius seperti depresi dan bunuh diri. Penelitian ini bertujuan untuk mengetahui tipe kepribadian dan status kesehatan mental pada kelompok risiko tinggi HIV/AIDS di wilayah kerja Puskesmas Ngemplak I.

Metode: Penelitian ini merupakan penelitian deskriptif dengan kuesioner Woodworth-Eysenck Inventory sebagai alat pengambilan data. Penelitian dilakukan pada bulan November 2020 dengan teknik purposive sampling pada Lembaga Swadaya Masyarakat (LSM) komunitas resiko tinggi HIV/AIDS yang bekerjasama dengan Puskesmas Ngemplak I dalam program Voluntary Counselling and Testing (VCT).

Hasil: Data yang didapatkan dari 20 responden menunjukkan bahwa 18 responden merupakan LSL dan 2 responden merupakan transgender dari lelaki menjadi perempuan. Data dari tes woodworth didapatkan $25 \%$ dari responden cenderung obsessive compulsive, 50\% memiliki kecenderungan schizoid, 35\% cenderung paranoid, 55\% cenderung depresi, $35 \%$ cenderung impulsif, 55\% cenderung memiliki ketidakstabilan emosi, dan $25 \%$ cenderung antisosial. Data dari tes eysenck menunjukkan bahwa $40 \%$ dari responden memiliki kecenderungan neurotik atau gangguan kecemasan dan $65 \%$ cenderung memiliki kepribadian introvert.

Kesimpulan: Mayoritas tipe kepribadian dari komunitas LSL dan transgender adalah kepribadian introvert dan linier dengan kecenderungan depresi. Pengenalan tipe kepribadian dan status kesehatan mental sedini mungkin dapat bermanfaat untuk mencegah adanya perilaku yang beresiko tinggi terhadap suatu penyakit bahkan dapat mencegah terjadinya depresi berat hingga percobaan bunuh diri.
\end{abstract}

Kata kunci: kepribadian, depresi, homoseks, transgender, HIV/AIDS.

\section{ABSTRACT}

Introduction: Homosexual and transgender are part of HIV/AIDS high risk population. The increasing of morbidity and mortality of HIV/AIDS in Indonesia should be overcome by any preventions and early detection of the contributing factors. Recognizing the personality and mental health status of the high-risk groups as early as possible can prevent the onset of a more serious disease or disorder such as depression and suicide attempt. This study aims to investigate the personality type and mental health status of the HIV/AIDS high risk population in the working area of Ngemplak I community health center.

Method: This is a descriptive study using woodworth-eysenck inventory as data collection tool. Data collection was conducted on November 2020 through purposive sampling technique. The respondents were the member of a NonGovernment Organization (NGO) focusing in sexually transmitted diseases and HIV/AIDS high risk community. This NGO was Ngemplak I Community Health Center partner in Voluntary Counselling and Testing (VCT) program.

Result: Data from 20 respondents showed that 18 respondents were homosexual (men having sex with men) and 2 of them were transgender (from men transformed into women). According to woodworth test, $25 \%$ of respondents tended to have obsessive compulsive personality, 50\% of them tended to have schizoid personality, $35 \%$ of them tended to have paranoid personality, $55 \%$ of them tended to have depression, 35\% of them tended to have impulsive personality, 55\% of them tended to have emotional instability, and $25 \%$ of them tended to have antisocial personality. Data from eysenck test revealed that $40 \%$ of them were having neurotic or anxiety disorder and $65 \%$ of them have introvert personality.

Conclusion: Most of the personality type from homosexual and transgender community involved in this study is introvert personality, leading to depression. Recognizing the personality type and mental 
health status as early as possible can be useful for preventing high-risk behavior for a disease as well as preventing severe depression and suicide attempt.

Keywords: personality, depression, homosexual, transgender, HIV/AIDS.

\section{PENDAHULUAN}

Data pada tahun 2019 mencatat 38 juta orang hidup dengan HIV di seluruh dunia, meningkat sebanyak 2 juta dibandingkan tahun 2016. Sebanyak 1.7 juta diantaranya merupakan kasus baru HIV. Afrika menduduki peringkat pertama dengan 25.7 juta orang yang hidup dengan HIV sementara posisi kedua adalah Asia Tenggara dengan 3.7 orang hidup dengan HIV. ${ }^{1,2}$ Indonesia berada di peringkat ke 13 dan merupakan negara pertama dengan jumlah kasus terbanyak di Asia Tenggara. Data dari Kemenkes RI tahun 2020 menunjukkan jumlah kasus HIV secara nasional sebanyak 388.724 kasus dan angka ini terus bertambah dari tahun ke tahun. ${ }^{3}$

Kasus HIV/AIDS di Daerah Istimewa Yogyakarta (DIY) cukup tinggi bila dibandingkan dengan daerah lain di Indonesia. Jumlah kasus di DIY sendiri hingga triwulan kedua 2019 tercatat sebanyak 4.990 orang dan yang sudah memasuki tahap AIDS sebanyak 1.689 orang. Rentang usia yang paling banyak hidup dengan HIV sejak tahun 2012-2016 dari data tersebut adalah usia 20-29 tahun. ${ }^{3}$ Penelitian yang berkaitan dengan berbagai faktor resiko penyakit ini terus dilakukan guna pencegahan dan pemutusan rantai penularan penyakit.

Kelompok resiko tinggi atau rentan mengalami HIV/AIDS selain terdiri dari penyalahguna napza suntik juga dari kelompok subyek dengan frekuensi bergonta ganti pasangan tinggi seperti Lelaki Suka Lelaki (LSL), Wanita Pekerja Seks (WPS) dan pelanggannya, waria penjaja seks dan pelanggannya, dan juga heteroseksual yang bergonta ganti pasangan. ${ }^{4-6}$ Beberapa penelitian sebelumnya menyebutkan bahwa pola asuh sejak kecil akan mempengaruhi terbentuknya pribadi yang termasuk kelompok rentan tersebut. Faktor lingkungan juga berperan besar terhadap perilaku, sikap dan juga pilihan orientasi seksual dari kelompok resiko tinggi ini. ${ }^{6-8}$

Lelaki Suka Lelaki (LSL) dan transgender dimana merupakan sebagian dari kelompok yang beresiko tinggi HIV/AIDS seiring berjalannya waktu jumlahnya semakin meningkat. ${ }^{6,9}$ Hal ini belum diimbangi dengan studi yang mempelajari lebih jauh tentang kelompok rentan ini di Indonesia. Penelitian sebelumnya yang dilakukan oleh Rzeszutek \& Gruszczyńska di tahun 2020 yang berjudul "Personality types and subjective well-being among people living with HIV: a latent profile analysis" menjelaskan gambaran kepribadian penderita HIV secara umum dengan subyek orang dengan HIV, tidak spesifik pada grup LSL atau transgender. ${ }^{10}$ Penelitian lain yang dilakukan oleh Pratiwi, Suwito, dan Hikmayani (2014) yang berjudul "Hubungan antara Penerimaan Diri dan Depresi pada Komunitas Gay di Surakarta" berfokus pada penerimaan diri komunitas LSL dan kondisi depresi yang dialami. ${ }^{11}$ Penelitian mengenai tipe kepribadian dan status mental pada kelompok resiko tinggi HIV/AIDS khususnya kelompok LSL dan transgender belum pernah dikaji secara mendalam di Indonesia. Gambaran kepribadian maupun kesehatan mental dari kelompok resiko tinggi HIV/AIDS ini sangat penting untuk dipelajari. Pengenalan kepribadian dan status kesehatan mental kelompok resiko tinggi sedini mungkin dapat mencegah timbulnya perjalanan penyakit atau gangguan yang lebih serius seperti depresi dan bunuh diri. Penelitian ini bertujuan untuk mengetahui tipe kepribadian dan status kesehatan mental kelompok resiko tinggi HIV/AIDS khususnya kelompok LSL dan transgender di wilayah kerja Puskesmas Ngemplak I.

\section{METODE}

Penelitian ini adalah penelitian deskriptif yang menggunakan kuesioner pengukuran 
Woodworth-Eysenck, salah satu instrumen yang digunakan untuk mendapatkan gambaran status mental dan kepribadian seseorang. Teknik sampling yang digunakan adalah purposive sampling pada kelompok orang beresiko tinggi terkena HIV/AIDS yang dalam studi ini ditujukan ke kelompok LSL dan transgender. Responden dari penelitian ini adalah seluruh anggota yang tergabung dalam sebuah LSM yang menaungi kelompok beresiko tinggi HIV/AIDS dimana anggota dari komunitas ini antara lain LSL dan transgender.

Woodworth Personality Inventory Test yang digunakan dalam penelitian ini menunjukkan 8 parameter psikopatologi, antara lain Emotional Infantile; sychasthenia, Obsesif (kelompok gangguan kecemasan umum, fobia, dan obsesif kompulsif); Kecenderungan Schizoid; Kecenderungan Paranoid; Depresi/ Hipokondria; Impulsif/ Epilepsi; Ketidakstabilan Emosi; serta Kecenderungan Antisosial. Alat tes Eysenck sendiri memiliki tiga parameter yang terukur yaitu Neurotic, Introvert, dan Kebohongan dalam menjawab tes.

Pengambilan data dilakukan pada bulan November 2020 bertepatan dengan penjadwalan VCT statis yang dilaksanakan di Puskesmas Ngemplak I sesuai dengan kesepakatan kerjasama dengan LSM kelompok beresiko tinggi HIV/AIDS tersebut. Setelah mendapatkan penjelasan mengenai penelitian ini dan responden bersedia untuk mengisinya, kemudian seluruh responden mengisi kuesioner pemeriksaan WoodworthEysenck dengan didampingi fasilitator dari Puskesmas. Kriteria responden yang mengikuti penelitian ini antara lain responden harus tergabung dalam LSM yang menaungi kelompok populasi beresiko tinggi HIV/AIDS dan tidak sedang didiagnosis mengalami gangguan kesehatan mental berat atau psikotik yang membutuhkan pengobatan antipsikotik. Responden yang sedang menjalani rawat inap di rumah sakit dan sedang mengkonsumsi obat - obatan terlarang dieksklusikan dari penelitian ini.
Data sekunder mengenai hasil test HIV dan Treponema Pallidum hemagglutination (TPHA) atau untuk mengetahui penyakit sifilis didapatkan dari rekam medis puskesmas. Data sekunder ini ditampilkan sebagai gambaran resiko yang dihadapi kelompok dalam penelitian ini. Data ini juga bermanfaat dalam deteksi dini dari HIV/AIDS. Data akan ditampilkan secara sederhana menggunakan tabel dengan kode dalam penamaan per subyek.

Analisis data dilakukan dengan menggunakan program Microsoft Excel yang telah diatur dengan perumusan untuk menampilkan grafik kecenderungan status mental responden berdasarkan dari data yang diisikannya. Pengolahan data dilakukan dengan skala nominal (Ya/Tidak) yang nantinya akan dimasukkan kedalam formula di mana Ya adalah 1 dan Tidak adalah 2. Analisa dari kuisioner Woodworth akan memiliki luaran grafik status kesehatan mental responden dan kuisioner Eysenck akan memiliki luaran tipe kepribadian responden pada saat pengisian.

\section{HASIL DAN PEMBAHASAN}

\section{Hasil}

Penelitian ini diikuti oleh 20 individu berisiko tinggi HIV/AIDS. Seluruh peserta yang datang untuk pemeriksaan VCT dijelaskan mengenai penelitian ini terkait gambaran status mental dan kepribadian. Tim peneliti meminta persetujuan tertulis kepada calon responden sebeum melakukan pengisian kuisioner Woodworth-Eysenck.

Data dari 20 responden yang mengisi kuisioner menunjukkan bahwa 18 responden merupakan LSL dan 2 responden yang merupakan transgender dari lelaki menjadi perempuan. Rentang usia responden yang terlibat dalam pengisian kuisioner ini cukup beragam dengan nilai rata-rata usia adalah 30 tahun, usia termuda adalah 21 tahun, dan usia tertua 55 tahun. Latar belakang pendidikan dari seluruh responden antara lain 5\% (1 orang) pendidikan terakhir SMP, 50\% (10 orang) 
pendidikan terakhir SMA, 15\% (3 orang) pendidikan terakhir SMK, 5\% (1 orang) pendidikan terakhir D3, dan 25\% (5 orang) merupakan Sarjana. Latar belakang pendidikan terbanyak dari responden adalah SMA dan yang setara (SMA dan SMK) yaitu sebanyak $65 \%$ (13 orang).

\section{Persebaran Usia Responden}

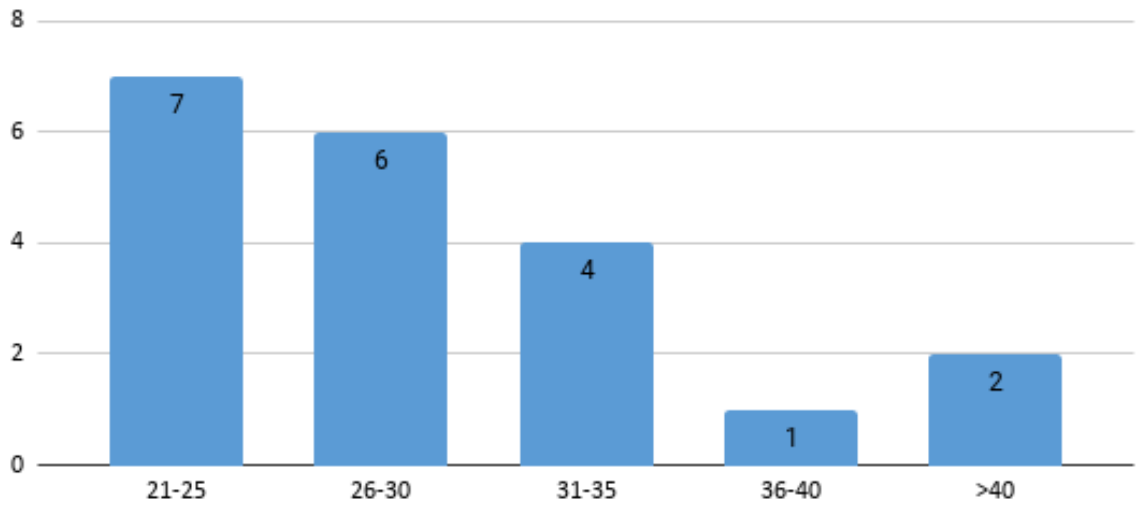

Gambar 1. Grafik Persebaran Usia Responden

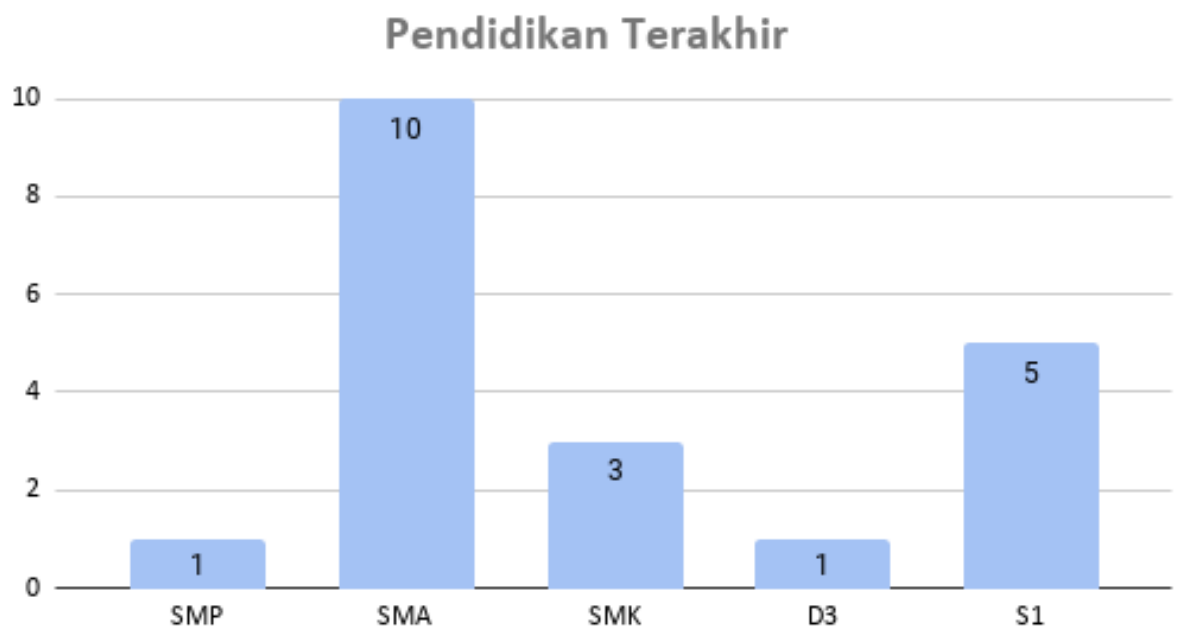

Gambar 2. Pendidikan Terakhir Responden

Responden didominasi oleh yang tinggal mandiri dengan menyewa kamar kost yaitu sebanyak 11 orang sementara sebanyak 5 orang tinggal dengan orang tua, 1 orang dengan kerabat, 1 orang dengan saudara kandung, 1 orang tinggal dengan istri, dan 1 orang tinggal sendiri. Data mengenai tipe pola asuh keluarga didapatkan dari responden sendiri. Tipe pola asuh terbanyak berdasar pengakuan responden adalah demokratis yaitu sebanyak $60 \%$, sedangkan pola asuh permisif 
dan otoriter masing - masing $20 \%$ berturutturut.

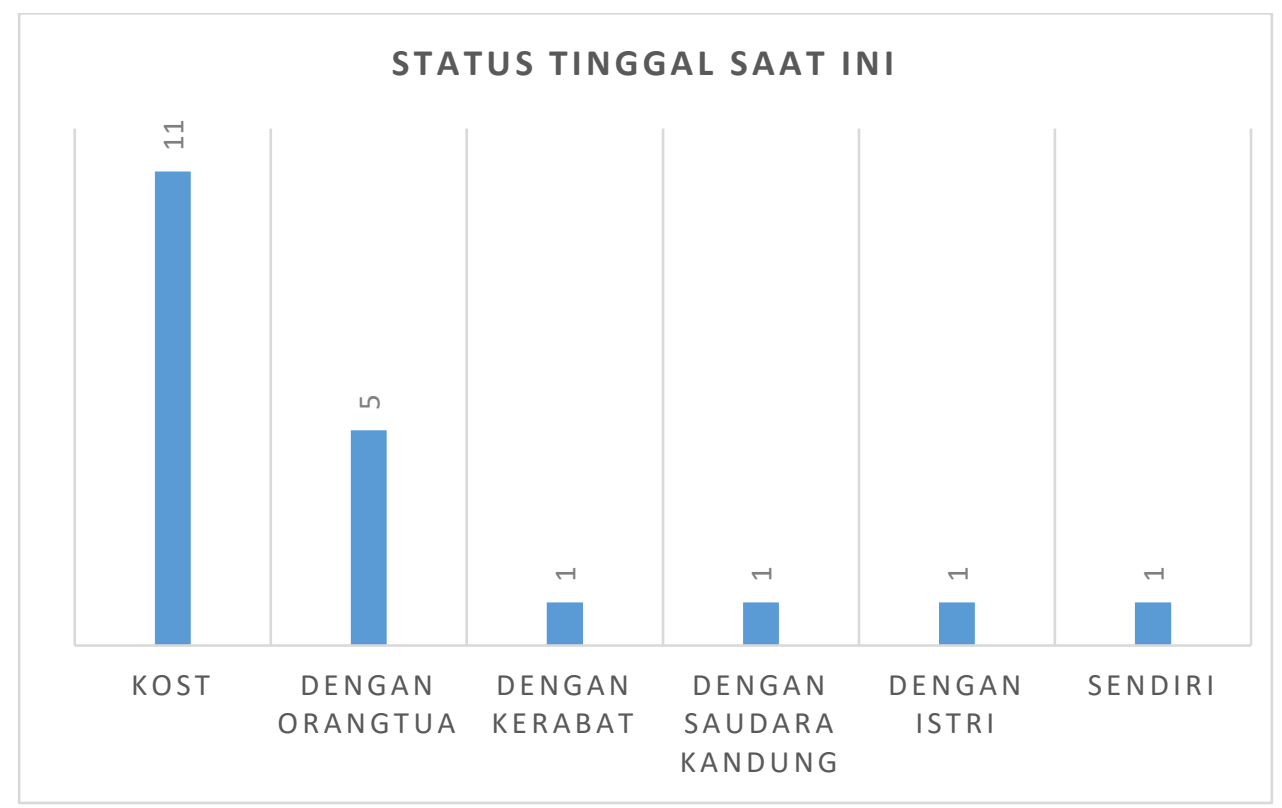

Gambar 3. Status Tinggal Responden

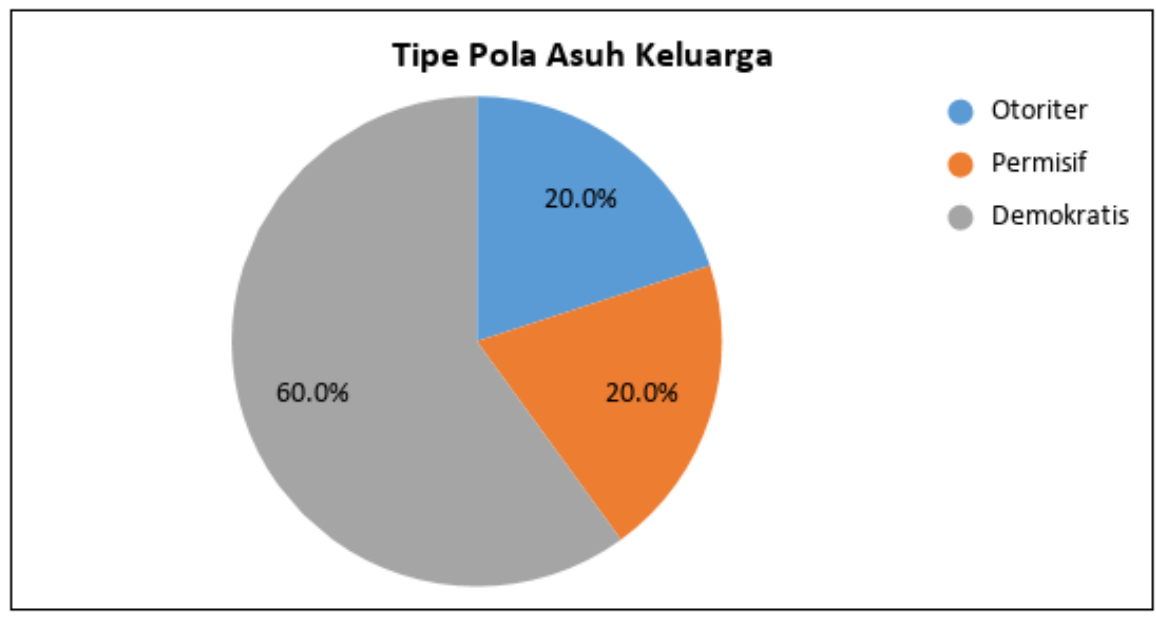

Gambar 4. Tipe Pola Asuh dalam Keluarga

Data sekunder mengenai hasil test HIV dan TPHA (Treponema Pallidum hemagglutination) didapatkan sebanyak 4 orang diketahui mengidap Shipilis dengan TPHA reaktif, dan sebanyak 1 orang suspek
HIV. 1 orang suspek HIV ini sudah pernah periksa di fasilitas kesehatan lain dengan hasil reaktif, namun ketika diulang di Puskesmas Ngemplak I hasilnya dua kali non reaktif, sehingga pasien disarankan untuk melakukan 
pemeriksaan ulang ELISA di Rumah Sakit rujukan namun hingga penelitian ini ditulis, pasien belum melakukan pemeriksaan ulang ELISA dengan alasan yang tidak diketahui. Responden masih tetap konsumsi terapi Antiretroviral (ARV) hingga saat penelitian dilakukan.

Woodworth Personality Inventory Test (WPIT) mengukur 75 pertanyaan yang harus dijawab responden dengan cepat, dengan jawaban Ya atau Tidak. Berdasar pemeriksaan WPIT, didapatkan data bahwa $25 \%$ dari responden cenderung Obsessive Compulsive, $50 \%$ memiliki kecenderungan Schizoid, 35\% cenderung Paranoid, 55\% Depresi, 35\% Impulsif, 55\% memiliki Ketidakstabilan Emosi, dan 25\% cenderung Antisosial.

Tabel 1. Hasil Tes Sifilis (TPHA) dan Rapid Tes HIV

\begin{tabular}{|c|c|c|c|c|}
\hline Kode & $\begin{array}{c}\text { Usia } \\
\text { (tahun) }\end{array}$ & $\begin{array}{c}\text { Kelompok } \\
\text { Resiko } \\
\text { Tinggi }\end{array}$ & TPHA & HIV \\
\hline 001 & 53 & Transgender & NR & NR \\
\hline 002 & 23 & LSL & $\mathrm{R}$ & NR \\
\hline 003 & 32 & LSL & NR & NR \\
\hline 004 & 55 & LSL & $\mathrm{R}$ & NR \\
\hline 005 & 37 & Transgender & NR & NR \\
\hline 006 & 29 & LSL & NR & NR \\
\hline 007 & 30 & LSL & NR & NR \\
\hline 008 & 22 & LSL & NR & NR \\
\hline 009 & 33 & LSL & NR & NR \\
\hline 010 & 24 & LSL & NR & NR \\
\hline 011 & 33 & LSL & $\mathrm{R}$ & NR \\
\hline 012 & 22 & LSL & NR & NR \\
\hline 013 & 30 & LSL & NR & NR \\
\hline 014 & 30 & LSL & NR & NR \\
\hline 015 & 24 & LSL & NR & NR \\
\hline 016 & 30 & LSL & NR & NR \\
\hline 017 & 26 & LSL & NR & NR \\
\hline 018 & 21 & LSL & NR & NR \\
\hline 019 & 22 & LSL & $\mathrm{R}$ & $\begin{array}{c}\text { Suspek, perlu } \\
\text { pengulangan }\end{array}$ \\
\hline 020 & 34 & LSL & NR & NR \\
\hline
\end{tabular}

Pemeriksaan lebih lanjut dengan tes Eysenck, dimana responden harus mengisi pertanyaan dengan jawaban Ya atau Tidak sebanyak 57 pertanyaan, diperoleh data bahwa $40 \%$ dari responden memiliki kecenderungan neurotik atau gangguan kecemasan, 65\% cenderung introvert, dan $100 \%$ responden mengisi kuisioner dengan jujur atau sesuai dengan kondisi yang dialami. 


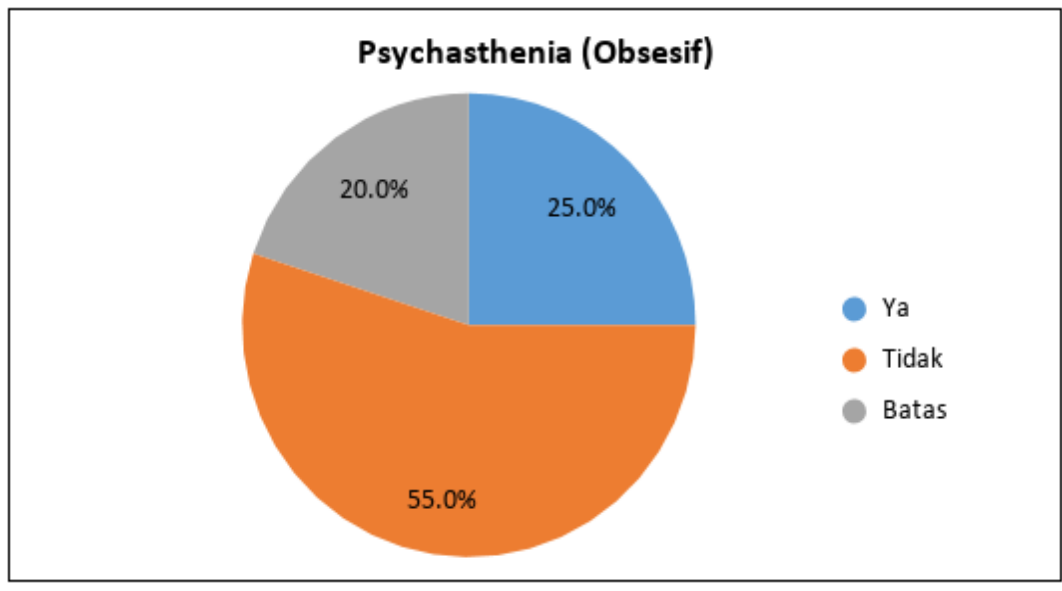

Gambar 5. Adanya Kecenderungan Psychasthenia (Obsesif)

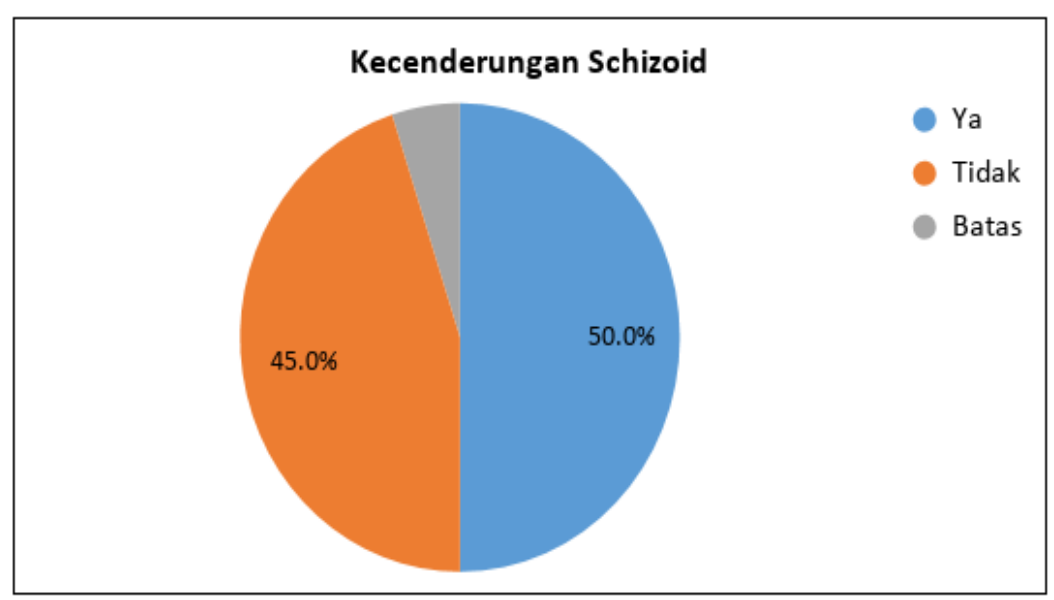

Gambar 6. Kecenderungan Schizoid

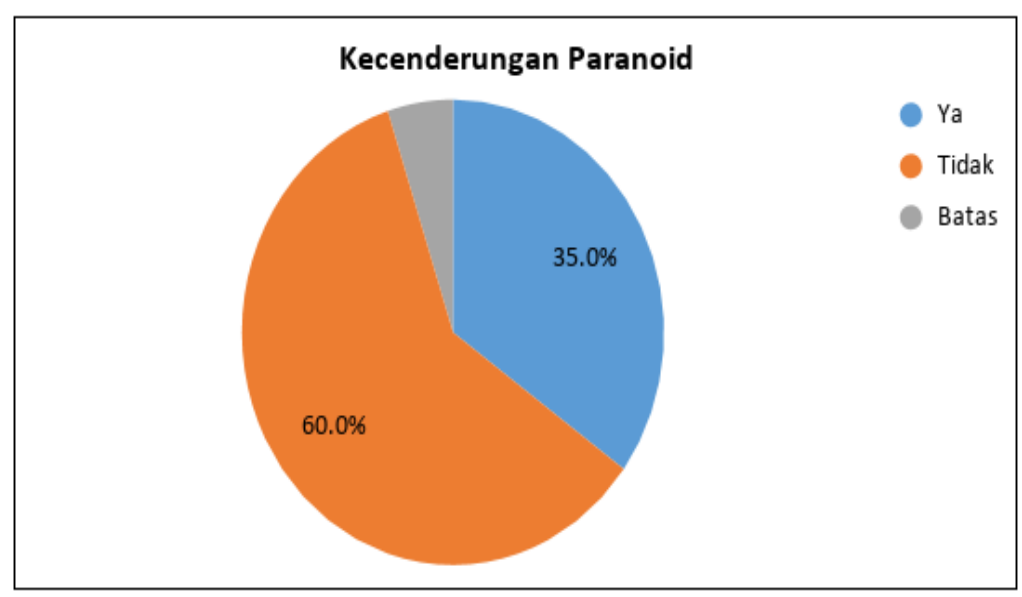

Gambar 7. Kecenderungan Paranoid 


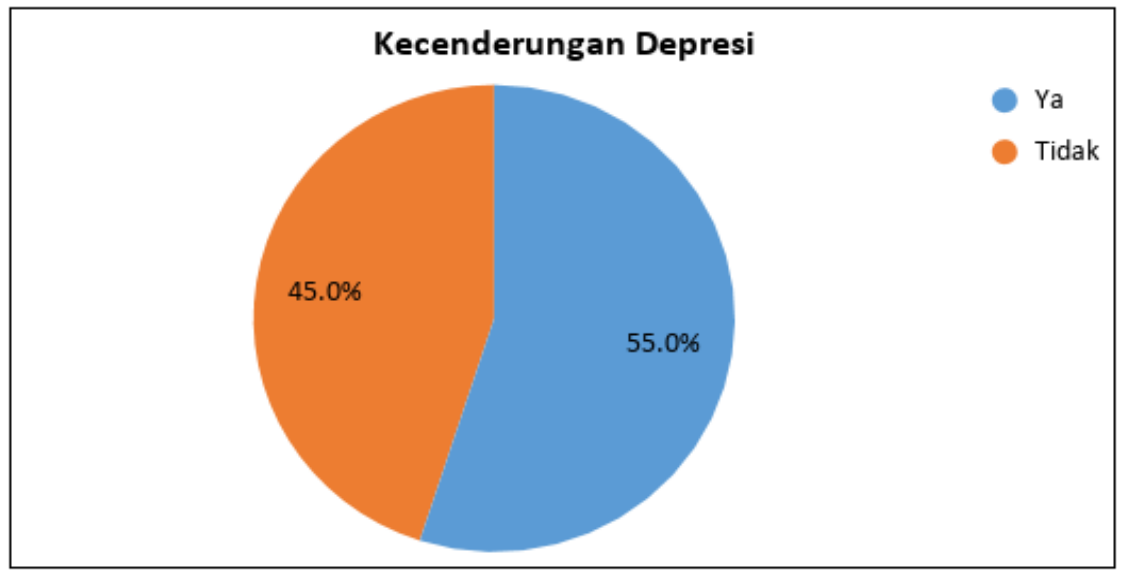

Gambar 8. Kecenderungan Depresi

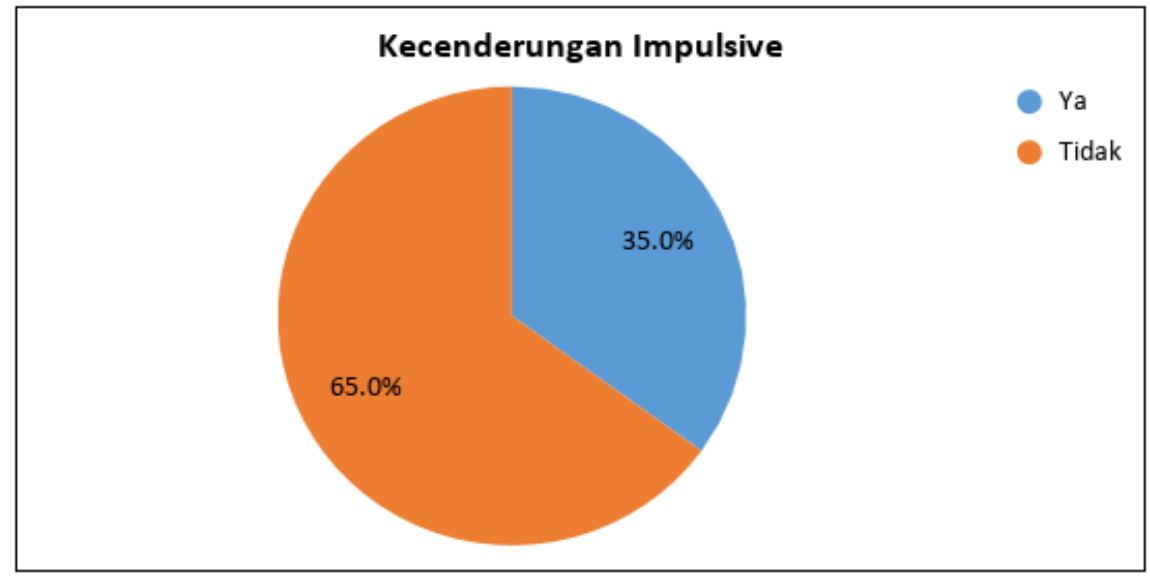

Gambar 9. Kecenderungan Impulsive

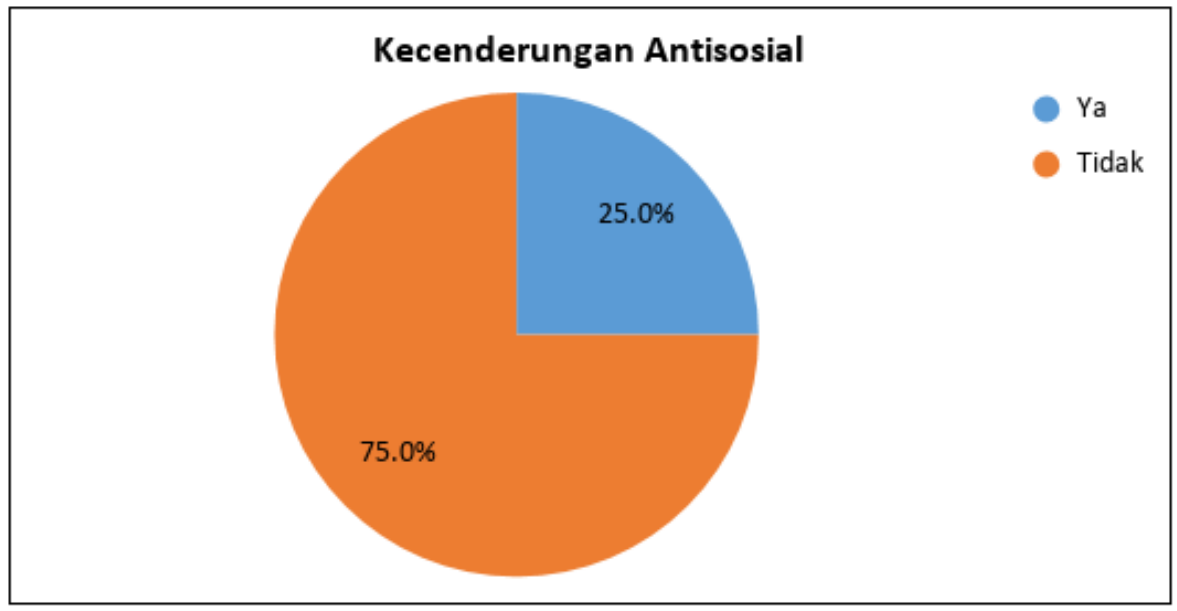

Gambar 10. Kecenderungan Antisosial 
MEDICA

ARTERIANA

(MED-ART)
Vol. 3 No. 1

JUNI 2021

p-ISSN : 2657-2370 e-ISSN : 2657-2389

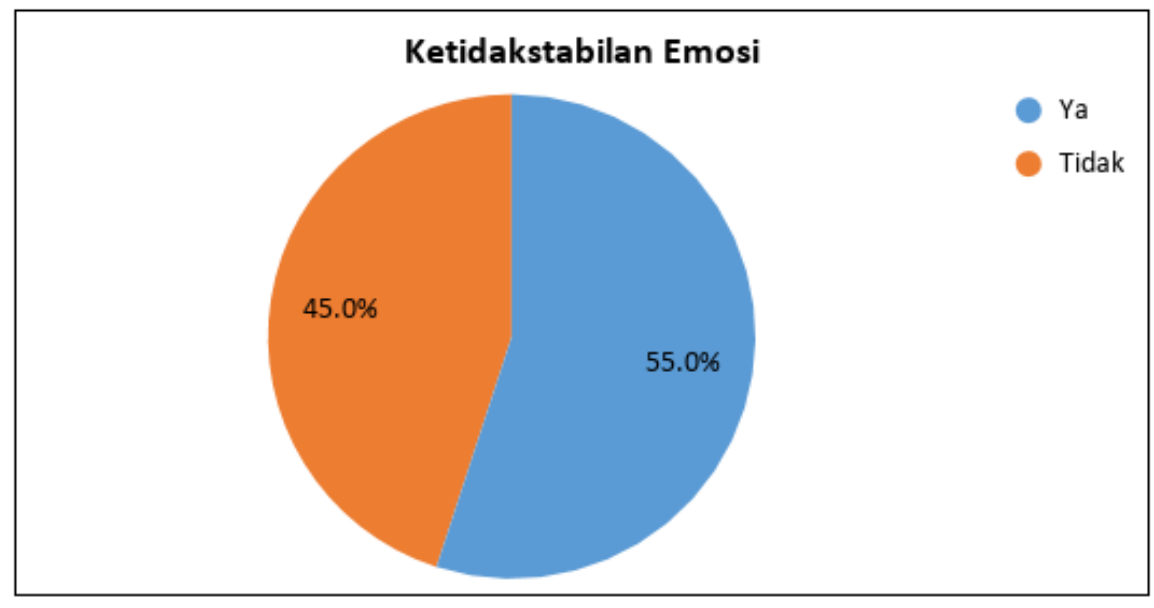

Gambar 11. Ketidakstabilan Emosi

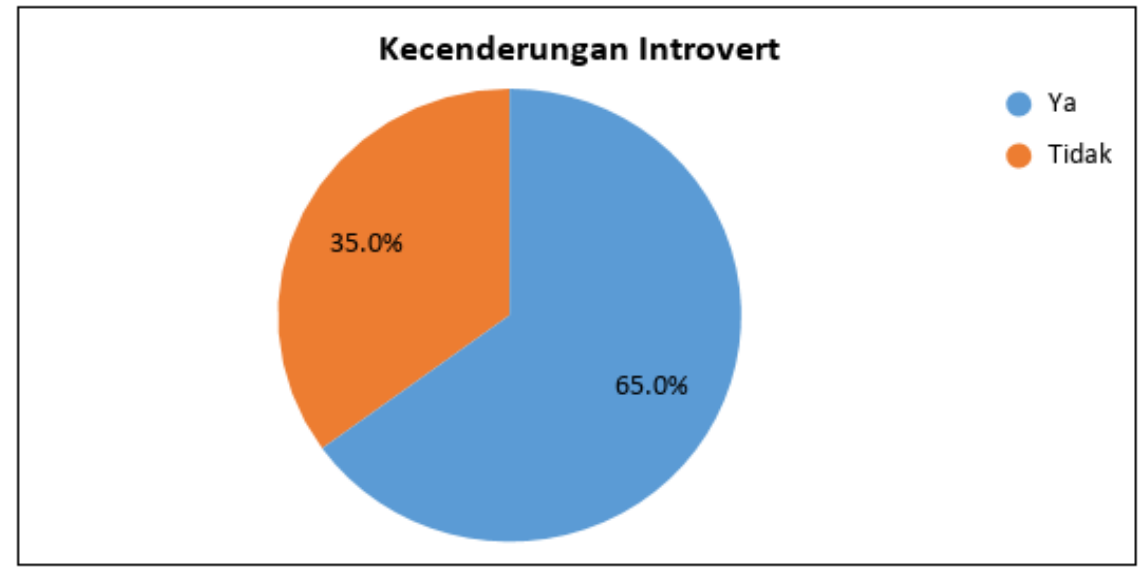

Gambar 12. Kecenderungan Kepribadian Introvert

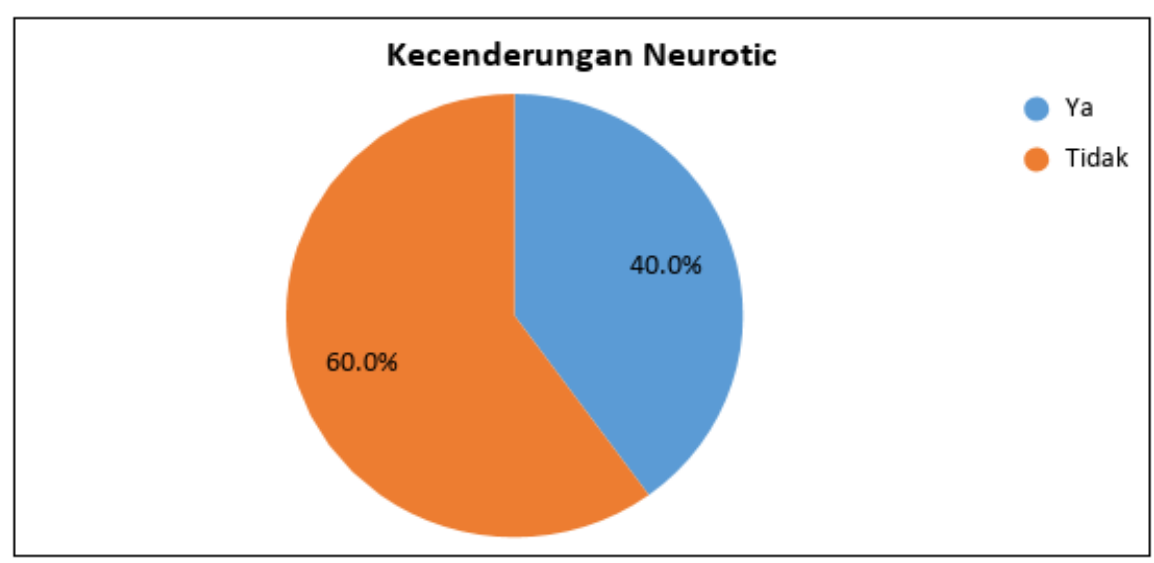

Gambar 13. Kecenderungan Neurotik 


\section{Pembahasan}

Human Immunodeficiency Virus (HIV) merupakan virus yang menyebabkan lemahnya sistem kekebalan tubuh, yang pada akhirnya menyebabkan Acquired Immunodeficiency Syndrome (AIDS). AIDS adalah sebuah kondisi medis yang berwujud lemahnya kekebalan tubuh, sehingga seringkali muncul manifestasi klinis berupa infeksi ikutan (infeksi oportunistik) hingga kanker. Penyakit ini pertama kali dilaporkan di tahun 1981 dan selama empat dekade ini telah menjadi pandemi. Penyakit ini masih menjadi hal yang menakutkan karena masyarakat percaya penyakit ini menular dan belum ada obat yang mampu menyembuhkan penyakit ini sehingga muncul stigma terhadap pengidapnya. ${ }^{1,12-15}$ Faktor resiko yang menyebabkan terjadinya penyakit ini antara lain perilaku seks menyimpang, berganti - ganti pasangan, dan penyalahgunaan obat terutama obat injeksi. ${ }^{16}$

Kelompok resiko tinggi HIV/AIDS selain pengguna Napza (Narkotika, Psikotropika, dan Zat Adiktif lainnya) suntik adalah kelompok yang sering berganti - ganti pasangan (promiskuitas) yang meliputi heteroseksual yang berganti - ganti pasangan dan pasangannya, Wanita Pekerja Seks (WPS) dan pelanggannya, Lelaki Suka Lelaki (LSL), Lelaki Penjaja Seks (LPS) dan pelanggannya, serta Waria penjaja Seks dan pelanggannya. ${ }^{14-}$ ${ }^{16}$ Kelompok resiko tinggi yang bersedia ikut sebagai respoden pada penelitian ini terdiri dari LSL dan transgender dari laki - laki yang mengubah dirinya menjadi perempuan. Kelompok ini termasuk dalam kategori yang umumnya saat ini disebut LGBT (Lesbian, Gay, Bisexual, Transgender).

Lelaki Suka Lelaki (LSL) atau yang juga sering disebut homoseksual, merupakan golongan orang yang memiliki kecenderungan ketertarikan terhadap sesama jenis. LSL umumnya saat ini disebut gay, sedangkan wanita suka wanita disebut lesbian. ${ }^{14,18}$ Sebelum tahun 1970, homoseksual masuk dalam kategori diagnosis gangguan mental berdasarkan Diagnostic and Statistical Manual of Mental Disorders (DSM) namun pada tahun
- tahun setelahnya, APA (American Psychological Association) meminta untuk tidak dimasukkan pada DSM sehingga DSM terbaru yaitu DSM V tidak menyebutkan bahwa homoseksualitas adalah salah satu bentuk gangguan mental. Kode diagnosis ICD 10 yang saat ini digunakan untuk koding di dunia kedokteran serta pada jaminan kesehatan nasional juga tidak menyebutkan dengan jelas bahwa Lesbian, Gay, Bisexual, and Transgender (LGBT) masuk dalam salah satu kode diagnosisnya. ${ }^{19,21}$ Kelompok kode F66 pada ICD 10 hanya menyebutkan tentang gangguan seksual lainnya (other sexual disorder). APA juga kemudian sedang mengajukan proposal kepada WHO untuk menghapus F66 ini dari grup kode diagnostik ICD $10 .{ }^{19}$

Terlepas dari apakah homoseksualitas dan transgender masuk dalam kategori diagnosis gangguan mental atau tidak, adanya tipe kepribadian introvert dan kecenderungan depresi sangat menonjol pada kelompok ini. ${ }^{11}$ Data yang paling menonjol dari studi ini adalah mayoritas populasi resiko tinggi HIV/AIDS adalah individu dengan tipe kepribadian introvert yaitu sebanyak $65 \%$, cenderung memiliki ketidakstabilan emosi yaitu sebanyak $55 \%$ dan mengalami depresi yaitu sebanyak $55 \%$. Responden yang mengikuti penelitian ini terdiri dari 18 LSL dan 2 transgender. Empat orang dari seluruh responden terdiagnosis syphilis dengan hasil test Treponema Pallidum hemagglutination (TPHA) reaktif sementara terdapat satu orang dengan suspek HIV dengan hasil tes rapid HIV reaktif satu kali kemudian diulang dengan hasil non reaktif dua kali sehingga saat ini dirujuk untuk dilakukan pemeriksaan ulang ELISA di Rumah Sakit.

Kepribadian introvert memiliki hubungan linier dengan kecenderungan mengalami depresi. Hal ini perlu diketahui lebih lanjut bahwa depresi merupakan suatu kondisi gangguan suasana perasaan yang ditandai dengan hilangnya minat, kegembiraan, mudah lelah, dan gangguan konsentrasi. ${ }^{11}$ Penelitianpenelitian sebelumnya menyebutkan faktor terjadinya depresi dipengaruhi juga oleh kepribadian seseorang, pada kepribadian 
ekstrovert kecenderungan untuk mendapatkan depresi lebih rendah dibanding kepribadian introvert. ${ }^{10,17}$ Diagnosis depresi dibagi menjadi tiga, yaitu ringan, sedang, dan berat. Perbedaan diantaranya diperlukan setidaknya dua minggu untuk menentukan derajatnya namun bisa juga kurang dari waktu tersebut apabila gejalanya sangat berat dengan onset yang cepat. Hal ini penting untuk diketahui karena depresi berat dapat mengakibatkan kematian melalui adanya keinginan untuk bunuh diri (tentamen suicide). ${ }^{17,20}$

Kepribadian merupakan ciri yang melekat pada diri seseorang yang menentukan bagaimana seseorang itu berpikir dan bersikap. Hal ini pulalah yang ikut menentukan bagaimana seseorang itu menerima keadaan, dan menentukan cara adaptasi seseorang. Kepribadian ditentukan oleh faktor genetik dan lingkungan yang kemudian tumbuh dan terbentuk melalui proses integrasi dari fungsi kognitif, konatif (karakter), afektif (temperamen) dan somatic. ${ }^{14,16,20}$ Berdasarkan pendekatan psikologis, kepribadian dibedakan menjadi kepribadian ekstrovert dan introvert.

Seseorang dengan kepribadian introvert muncul dengan ciri ketenangan, subyektif, sering murung, sedikit bicara, sering merasa cemas atau khawatir, malu, kurang nyaman dan tidak menyukai pergaulan yang ramai dengan banyak orang, rasa ragu-ragu, defensif, tertutup, pasif dan pesimis. ${ }^{7,8,9,17}$ Seorang introvert biasanya cenderung lebih bertanggungjawab terlepas dari karakteristik lain yang telah disebutkan. Adanya dua tipe kepribadian ini tidak membuat individu hanya memiliki kepribadian ekstrovert atau introvert saja. Sebagian besar individu akan memiliki keduanya, dan hanya sedikit orang yang cenderung kearah salah satu dari dua kepribadian tersebut. ${ }^{17}$

Gambaran kepribadian introvert hampir sama dengan manifestasi depresi. Individu dengan kepribadian introvert cenderung lebih rentan dalam menghadapi kejadian traumatik. Hal ini disebabkan karena ketahanan kendali diri yang lebih lemah dibanding individu yang ekstrovert. Seorang introvert akan lebih mudah mengingat kejadian traumatik dan lebih mudah berkembang menjadi gejala depresif. ${ }^{11,17,20}$ Depresi ringan, sedang dan berat juga ditemukan pada komunitas gay yang sudah pernah diteliti di Surakarta oleh Pratiwi, N.A., dkk, di tahun 2014. Penelitian tersebut juga menemukan adanya penerimaan diri yang rendah pada komunitas gay yang diyakini disebabkan dari penolakan sosial mengenai pilihan orientasi seksual. ${ }^{11}$

Mayoritas responden yang terlibat dalam penelitian ini memiliki tipe kepribadian introvert, yang mana lebih mudah untuk mengalami depresi. Pilihan orientasi seksual yang dijalani saat ini sebenarnya bertentangan dengan norma masyarakat Indonesia. Masyarakat Indonesia didominasi sistem sosial dan orientasi heteroseksual. Penolakan terhadap homoseksual dengan stigmanya masih sangat kuat beredar di masyarakat. Secara aspek legal, Indonesia juga hanya mengakui dua jenis kelamin yaitu laki-laki dan perempuan, wanita-pria atau waria tidak mendapat pengakuan secara administratif dan hukum. ${ }^{11}$ Orang dengan pilihan orientasi seksual yang berbeda di masyarakat pada umumnya maka akan cenderung merahasiakannya dari orang lain. Dengan dasar kepribadian introvert, tentunya merahasiakan kondisi orientasi seksual yang berbeda dengan norma di masyarakat hampir pasti dilakukan. Adanya konflik diri yang cukup besar ini semakin menunjang potensi terjadinya depresi. Hal lain yang perlu diperhatikan adalah bahwa komunitas resiko tinggi ini juga menyadari bahaya potensi penyakit (HIV/AIDS) yang mengancam mereka sehingga beban pikiran akan bertambah. Hal ini merupakan stressor yang cukup berat bagi kelompok resiko tinggi HIV/AIDS dengan kepribadian introvert dan bisa memicu terjadinya depresi berat hingga percobaan bunuh diri. ${ }^{10,11}$

Emosi yang tidak stabil ditemukan sebesar $55 \%$ dari seluruh responden, sementara usia terbanyak dari responden adalah usia $21-25$ tahun atau dewasa muda. Ketikstabilan emosi biasanya didapatkan pada usia remaja, namun pada penelitian ini masih nampak pada usia dewasa muda yang merupakan golongan usia 
lepas remaja ${ }^{7,8}$. Hal ini masih sangat mungkin karena usia dewasa muda adalah usia yang juga masih mencari jati diri sesungguhnya. Ketidakstabilan emosi yang ditemukan pada kelompok resiko tinggi pada penelitian ini juga bisa disebabkan oleh adanya perasaan sebagai kaum minoritas yang takut hidup sendirian, ditinggal oleh pasangannya, dan juga tidak diterimanya individu tersebut di tengah keluarga atau masyarakat ${ }^{8,9}$. Faktor lain yang sangat kuat hubungannya adalah kejadian traumatis yang dialami. Contoh kejadian traumatis tersebut adalah pelecehan seksual pada anak yang dapat mengakibatkan perubahan perilaku dan emosi dalam merespon sesuatu. Hal ini disebabkan adanya memori tidak menyenangkan yang muncul sebagai respon dalam menerima atau mempersepsikan suatu kejadian. Perubahan-perubahan emosi ini bisa berupa mudah marah, agresif, pendiam, atau menutup diri. ${ }^{17,18}$

Mengenali tipe kepribadian dan status kesehatan mental anggota keluarga sedini mungkin dapat mebantu mencegah timbulnya potensi penyimpangan sikap, perilaku, dan bahkan pemilihan orientasi seksual yang beresiko tinggi terhadap terjadinya HIV/AIDS. Temuan dari berbagai penelitian yang saling mendukung ini dapat dijadikan ilmu pengetahuan untuk lebih menyadari pentingnya kesehatan mental individu sehingga kejadian yang tidak diharapkan yang berakibat fatal dapat dicegah. Benang merah yang dapat ditarik dari penelitian ini adalah bahwa mayoritas individu dengan orientasi seksual penyuka sejenis atau homoseksual adalah mereka dengan latar belakang kepribadian introvert dan cenderung mudah mengalami depresi. ${ }^{16,18}$ Kepribadian terbentuk tidak hanya dari genetik melainkan juga pengaruh pola asuh dalam keluarga, kejadian traumatis, dan faktor lingkungan. ${ }^{10,17}$

Keterbatasan dari penelitian ini antara lain belum tergalinya penilaian hubungan dalam keluarga seperti konflik yang terjadi di dalam keluarga. Data yang diperoleh yang berdasar laporan diri responden hanya menyatakan jenis pola asuh namun data lain seperti adanya trauma masa kecil, konflik dalam keluarga, dan kondisi lingkungan sekitarnya belum tergali. Adanya disfungsi keluarga dan kejadian traumatik yang didapat baik dari keluarga maupun lingkungan sekitar merupakan faktor yang turut berkontribusi terhadap terwujudnya perilaku menyimpang yang beresiko tinggi terhadap HIV/AIDS. Keterbatasan lainnya adalah diagnosis depresi yang dideteksi oleh alat ukur woodworth tidak dapat dikategorikan menjadi ringan, sedang atau berat. Alat ini hanya mendeteksi adanya kecenderungan depresi atau tidak sehingga diperlukan pemeriksaan lanjutan berdasarkan kriteria diagnostik dari DSM V atau Pedoman Penggolongan dan Diagnosis Gangguan Jiwa di Indonesia (PPDGJ) atau dengan menggunakan skala penilaian depresi antara lain Beck Depression Inventory (BDI).

\section{KESIMPULAN}

Gambaran tipe kepribadian yang paling banyak ditemukan pada kelompok resiko tinggi HIV/ AIDS yang dalam penelitian ini terdiri dari kelompok LSL dan transgender adalah tipe kepribadian introvert. Introvert adalah gambaran kepribadian yang serupa dengan manifestasi klinis dari depresi.

Kondisi mental yang paling menonjol pada studi ini linier dengan gambaran mayoritas tipe kepribadian yaitu adanya kecenderungan depresi dan ketidakstabilan emosi. Pengenalan tipe kepribadian dan status kesehatan mental sedini mungkin pada anggota keluarga dapat bermanfaat untuk mencegah adanya perilaku yang beresiko tinggi terhadap suatu penyakit, bahkan dapat mencegah terjadinya depresi berat hingga percobaan bunuh diri. Pengenalan tipe kepribadian dan status kesehatan mental pada individu yang telah masuk dalam kelompok resiko tinggi HIV/ AIDS yang dalam penelitian ini adalah LSL dan transgender, dapat membantu konselor atau terapis dalam pendampingan dan menemukan jalan terbaik untuk meningkatkan kualitas hidup yang sejahtera secara fisik dan psikologis.

\section{DAFTAR PUSTAKA}


1. World Health Organization. HIV data and statistics. 2020 Available from: URL: HIPERLINK:

https://www.who.int/hiv/data/en/

2. UNAIDS. Global HIV \& AIDS statistics 2019 fact sheet. 2020 Available from: URL: HIPERLINK: https://www.unaids.org/en/resources/factsheet

3. Kementerian Kesehatan RI. Infodatin HIV AIDS;2020. Pusat Data dan Sistem Informasi Kementrian Kesehatan RI. Ditjen P2P (Sistem Informasi HIV/AIDS dan IMS (SIHA), Laporan Tahun 2019.

4. Hasnah, Alang S. Lesbian, gay, biseksual dan transgender (lgbt) versus kesehatan: studi etnografi. Jurnal Kesehatan. 2019;12(1): 63-72.

5. Al-Farisy AF. 2018. Kendala lgbt (lesbian, gay, biseksual, transgender) untuk beralih menjadi heteroseksual di yayasan gaya mahardhika kota surakarta. [Skripsi]. Surakarta: Universitas Muhammadiyah Surakarta.

6. Hartono A. Faktor risiko kejadian penyakit menular seksual (pms) pada komunitas gay mitra strategis perkumpulan keluarga berencana indonesia (PKBI) yogyakarta. Journal of Chemical Information and Modeling. 2013;15(9): 1689-1699.

7. Lothwell, LE, Libby N, Adelson, SL. Mental health care for lgbt youths. Focus. 2020 summer;18(3): 268-276.

8. Kim HJ, Fredriksen-Goldsen KI, Bryan AEB, Muraco A. Social network types and mental health among lgbt older adults. Gerontologist. 2017;57(Suppl 1): S84S94.

9. Collins PY, Holman AR, Freeman MC, Patel V. What is the relevance of mental health to HIV/AIDS care and treatment programs in developing countries? A systematic review. AIDS. 2006 August 1;20(12): 1571-1582.

10. Rzeszutek M, Gruszczyńska E. Personality types and subjective wellbeing among people living with HIV: a latent profile analysis. Quality of Life Research. 2020;29: 57-67.

11. Pratiwi NA, Suwito D, Hikmayani NH. Hubungan antara penerimaan diri dan depresi pada komunitas gay di surakarta. Nexus Kedokt Komunitas. 2014;3(1): 92101.

12. Remiena RH, Stirratt MJ, Nguyen N, Robbins RN, Pala AN, and Mellins. CA. Mental health and HIV/ AIDS: The need for an integrated response. AIDS. 2019; 33: 1411-1420.

13. Kemenkes. Laporan Nasional RISKESDAS 2018. Badan Penelitian dan Pengembangan Kesehatan. Available from: URL: HIPERLINK: http://labdata.litbang.kemkes.go.id

14. Kana IMP, Nayoan CR, Limbu R. Gambaran perilaku pencegahan hiv dan aids pada lelaki suka lelaki (lsl) di kota kupang tahun 2014. Unnes Journal of Public Health. 2014;5(3): 252.

15. Wati EE, Lubis R, Rochadi RK. The effects of multiple sexual partners and condoms use on the incidence of hiv in men having sex with men. Journal of Health Promotion and Behavior. 2018;3(3): 150-154

16. Rokhmah D. Pola asuh dan pembentukan perilaku seksual berisiko terhadap hiv/aids pada waria. Jurnal Kesehatan Masyarakat. 2015;11(1): 125

17. Manovia W. Perbedaan tingkat depresi berdasarkan tipe kepribadian ekstrovert dan introvert pada mahasiswa tingkat I fakultas kedokteran UNS. 2011. [Skripsi]. Surakarta: Universitas Sebelas Maret Surakarta.

18. Hardisman, Firdawati, Sulrieni IN. Model determinan perilaku "lelaki seks lelaki" di kota padang, sumatera barat. Jurnal Kesehatan Andalas. 2018;7(3): 305.

19. American Psychological Association. APA Proposes deletion of sexual orientation diagnoses in ICD-10. 2011. Available from: URL: HIPERLINK: https://www.apa.org/pi/lgbt/resources/icd $-10$ 
20. Mundle G, Mahler L, Bhugra D. Homosexuality and mental health. International Review of Psychiatry. 2015; 27(5): 355-356.

21. Russell ST, Fish JN. Mental health in lesbian, gay, bisexual, and transgender (LGBT) youth. Annual Review of Clinical Psychology. 2016;12: 465-487.

22. Sidjabat FN, Setyawan H, Sofro MAU, Hadisaputro S. Lelaki seks lelaki, HIV/AIDS dan perilaku seksualnya di semarang. Jurnal Kesehatan Reproduksi. 2017;8(2): 131-142. 